\title{
PARADIGM SHIFT: FEDERAL SECURITIES REGULATION IN THE NEW MILLENNIUM
}

\author{
Steven M. Davidoff
}

\section{INTRODUCTION}

In May 2007, Oaktree Capital Management LLC, a U.S.-based hedge fund adviser with over $\$ 40$ billion in assets under management, sold approximately $14 \%$ of its equity for more than $\$ 800$ million in a widespread underwritten offering to a number of prospective purchasers. ${ }^{1}$ If the offering had been a public one it would have been the year's sixth-largest initial public offering by a domestic issuer. ${ }^{2}$ But Oaktree deliberately chose not to raise this capital on the public market, thereby forgoing a listing on the New York Stock Exchange (NYSE) or Nasdaq. Instead, Oaktree made its initial offering on the U.S. private market. The company thereafter listed its equity securities on Goldman Sachs \& Co.'s non-public market, the "GS Tradable Unregistered Equity OTC Market" (GSTrUE). ${ }^{3}$ On the heels of this offering, Apollo Management L.P., a private equity fund adviser, conducted a similarly structured equity offering, privately raising $\$ 828$ million and immediately thereafter listing the equity securities on GSTrUE. ${ }^{4}$

These two offerings were historically extraordinary. They were the first two substantial underwritten offerings and listings of domestic equity securities on a U.S. private rather than public market. ${ }^{5}$ The two offerings

* Assistant Professor of Law, Wayne State University Law School. B.A., University of Pennsylvania; J.D., Columbia University School of Law; M.S., Finance, London Business School. The author would like to thank Erica Beecher-Monas, Peter Henning, Noah Hall and the faculty work-shop attendees at AALS for their helpful comments and suggestions, as well as Laura Berdish at the University of Michigan Business School library and Joshua Terebelo for their invaluable research assistance. Portions of this essay will first appear in Steven M. Davidoff, Black Market Capital, 2008 ColUM. BUS. L. REV. 172 (2008). This paper was prepared for and presented at the 2008 meeting of the American Association of Law Schools Securities Regulation Section and is included in this Journal as part of those papers.

1. See Tom Petruno, Oaktree in Private Share Offering, L.A. TIMES, May 23, 2007, at C1.

2. Bloomberg Terminal Database (search data on file with author). The figure excludes initial public offerings by special purpose acquisition companıs.

3. See Petruno, supra note 1.

4. See Apollo Raises $\$ 828$ Million, WaLL ST. J., Aug. 7, 2007, at C6. Neither Oaktree nor Apollo explained the reason for a private equity offering and listing rather than a public one. Commentators speculated that the decision was made to avoid application of U.S. securities laws which the offerors perceived as unduly burdensome and restrictive. See Petruno, supra note 1; Henny Sender, Live at Apollo Management: Plan to Cash in, Limit Scrutiny, WaLl ST. J., July 17, 2007, at Cl. On April 8, 2008, Apollo Global Management filed a registration statement on Form S-1 to register with the SEC the shares issued in its offering on GSTRuE. In its filing Apollo announced that it would transfer the listing of its equity securities from GSTRuE to the New York Stock Exchange (NYSE). See Apollo Global Mgmt., LLC, Registration Statement (Form S-1), at cover, (Apr. 8, 2008). It appears that the registration of these securities and move to the NYSE was contemplated at the time of Apollo's initial offering on GSTRuE. Apollo's GSTRuE offering may therefore have been a transitory way for Apollo to immediately sell equity interests rather than incurring the delay of a more time-consuming registration process.

5. See Sender, supra note 4. 
are also emblematic of a paradigm shift occurring in the capital markets: The market for capital is increasingly competitive and global, viable public and private markets are proliferating world wide, domestic investing patterns are changing as intermediary investing and deretailization occur, and financial innovation is quickening. The result is an on-going, perhaps revolutionary, transformation in the scope and structure of the global and domestic capital markets. The shift is already providing issuers with nontraditional options for capital-raising and risk management, the former illustrated by the Oaktree and Apollo offerings. ${ }^{6}$ And it may alter core assumptions about the optimal capital structure for corporate entities as issuers spurn public equity markets for alternative markets and financial products to replace their traditional capital sources. ${ }^{7}$

This paradigm shift is also calling into question the necessary parameters and content of securities regulation. In a more competitive and transformed capital market, historical federal securities regulation is increasingly inapposite and in need of reform. However, regulatory action is also more difficult as markets provide ever more viable choices and the ability to structure capital needs to circumvent such regulation. ${ }^{8}$ This "subrevolution" in regulatory calculus is one that the Securities and Exchange Commission (SEC) has yet to significantly account for in its rule-making process. Instead, the SEC continues to regulate largely without heed to this transformed landscape. ${ }^{9}$

This essay concerns this paradigmatic shift in the capital markets and its implications for the SEC regulatory process and the future of federal securities regulation. Part I sets forth three significant developments in the new capital market: the global proliferation of viable private and public markets, the trend of investment intermediation and deretailization, and the accelerated pace of financial innovation. Part II highlights the failure of the SEC to account for these events. The SEC's current regulatory process, to the extent it historically produced functional regulation, no longer achieves this end in a variety of contexts. The recent SEC rule-making experience with respect to hedge funds highlights both the flaws in current SEC rulemaking and the Agency drivers producing this regulation.

6. See discussion infra Part I.A.

7. See discussion infra Part I.C, which details these developments in the context of the recent wave of private equity acquisitions and the private market it fosters.

8. Illustratively, if the SEC promulgates regulation which is, in aggregate effect, socially beneficial but imposes a particular economic burden on issuers raising public capital, these issuers can increasingly respond by forgoing this option instead of resorting to less regulated private or non-U.S. markets offering competitive alternatives.

9. To be fair, despite its inaction, the SEC has publicly recognized some of these forces. In a recent speech at University of Pennsylvania Law School, Brian G. Cartwright, General Counsel of the SEC, spoke extensively on the deretailization trend in the U.S. securities markets. See Brian G. Cartwright, Gen. Counsel, SEC, Speech at the University of Pennsylvania Law School Institute for Law and Economics: The Future of Securities Regulation (Oct. 24, 2007), avalable at http://www.sec.gov/news/speech/2007/spch102407bgc.htm [hereinafter Cartwright Speech]. 
The essay concludes by briefly assessing the prospects for federal securities reform and suggests a new SEC regulatory-process model grounded in regulatory cost-benefit analysis. A new global capital market landscape is inexorably being created, a reality that the SEC will inevitably have to acknowledge as the flaws in its current regulation and regulatory approach are increasingly teased forth. It is a transformation that has a real chance to engender substantive change in the scope, structure and content of the federal securities laws. The SEC will inevitably be forced to act. If the SEC promulgates regulation that not only pays heed to the new capital markets paradigm, but does so in a manner comporting with sound regulatory process, it will do so in a more economical and responsive manner.

\section{THE NEW PARADIGM}

\section{A. Market Proliferation}

Securities markets are proliferating globally, growing in prominence and meaningfully competing with the regulated U.S. public securities market. The primary regulatory consequences are manifold. First, as securities offering activity increasingly occurs on these alternative markets, the U.S. public securities market-the regulatory focus of the SEC-is rapidly losing its dominant position as the principal place to raise equity capital. ${ }^{10}$ Second, market proliferation exposes a dilemma for the SEC. The simple prohibition or regulation of a security is no longer a complete regulatory solution. In such a circumstance, prohibitory or restrictive regulation of this nature will simply cause trading or investing in the relevant security to migrate to foreign or private markets. Third, this shift raises issues and prospects of enhanced SEC regulation of private markets to the extent that it implicates the SEC's regulatory mission - the protection of investors and the integrity of markets generally. ${ }^{11}$

\section{The Private Domestic Offering and Trading Market}

The private securities offering market in the United States is structured to comply with the federal securities law exemptions for registration of securities. Generally, as long as an issuer solicits and raises capital from investors with a certain aggregate minimum net worth, the offering need not be registered and only limited provisions of the securities laws apply,

10. See generally COMM. ON CAPITAL MKTS. REGULATION, INTERIM REPORT 29-39 (2006), available at http://www.capmktsreg.org/research.html [hereinafter INTERIM CAPITAL MARKETS REPORT] (surveying the market for global listings and arguing that the U.S. markets are in comparative competitive decline).

11. The movement of securities offering and trading to these alternative markets also raises investor equality issues as retail investors are increasingly deprived of investing opportunities. 
primarily the anti-fraud strictures. ${ }^{12}$ For purposes of underwritten and widespread offerings, the principal private exemption relied upon is the Rule 144A exemption under the Securities Act of 1933, as amended (Securities Act) ${ }^{13}$ Rule 144A exempts securities offerings from the resale restrictions of the Securities Act as long as the offering is confined to qualified institutional buyers. ${ }^{14}$ These buyers are generally institutional investors who hold more than $\$ 100$ million worth of securities. ${ }^{15}$

Historically, this market was largely comprised of non-domestic issuers offering equity securities in the United States, and domestic and nondomestic issuers offering debt securities in the United States. ${ }^{16}$ However, the Rule 144A market for domestic issuers of equity has experienced extraordinary growth in recent years. Chart $1 \mathrm{~A}$ sets forth the aggregate amount of equity raised by domestic issuers in initial public offerings versus private Rule 144A placements for the period 2000 through 2007.

Chart 1A $\mathbf{A}^{17}$

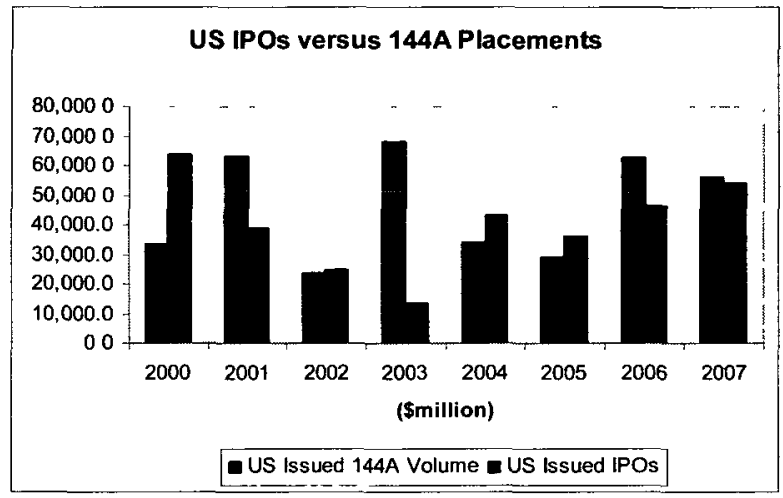

12. See generally C. Edward Fletcher, III, Sophisticated Investors Under the Federal Securities Laws, 1988 DUKE L.J. 1081, 1119-20 (examining the treatment of sophisticated investors under the Securities Act of 1933, as amended).

13. 17 C.F.R. $\S 230.144 \mathrm{~A}$ (2007). Issuers can only utilize the Rule $144 \mathrm{~A}$ safe-harbor to offer securities that are not listed on a national securities exchange. Id. at $\S 230.144 \mathrm{~A}(\mathrm{~d})(3)(\mathrm{i})$. See generally Luis F. Moreno Trevino, Access to U.S. Capital Markets for Foreign Issuers: Rule $144 \mathrm{~A}$ Private Placements, 16 Hous. J. INT'L L. 159, 195 (1993) (outlining the typical structure of a Rule 144 A offering).

14. 17 C.F.R. \& 230.144A.

15. Id.; see also Resale of Restricted Securities, Changes to Method of Determining Holding Period of Restricted Securities Under Rules 144 and 145, Securities Act Release No. 6862, [19891990 Transfer Binder] Fed. Sec. L. Rep. (CCH) I 84,523, at 80,641-42 (Apr. 23, 1990). Generally, a corporate issuer is classified under the U.S. securities laws as either a U.S. domestic issuer or a foreign private issuer. Foreign private issuers benefit from certain exemptions under the U.S. securities laws that are not available to U.S. domestic issuers. For simplicity's sake, throughout this essay, foreign private issuers are also referred to as "non-U.S. companies," "nonU.S. issuers," or "foreign companies" and are generally deemed to refer to foreign companies.

16. Technically the Rule 144A offering exemption is utilized by the underwriter. The issuer sells the securities to the underwriter under the private offering exemption under Section 4(2) of the Securities Act or Regulation D. See Trevino, supra notc 13, at 173-81.

17. Dealogic Database, 144A \& U.S. Issued IPOs (search data on file with author). 
In 2007 , Rule $144 \mathrm{~A}$ equity offerings by domestic issuers raised $\$ 56.387$ billion, an amount greater than the $\$ 54.289$ billion raised in domestic issuer public offerings. The bulk of the Rule 144A equity raised and included on Chart $1 \mathrm{~A}$ was raised in the form of debt convertible into equity. ${ }^{18}$ Still, in $2007 \$ 4.5322$ billion was raised in Rule 144A offerings of equity not issued in connection with an issuer's initial public offering. ${ }^{19}$

This eclipse is more evident in the non-domestic issuer market. Chart $1 \mathrm{~B}$ sets forth the number of, and aggregate dollar amount raised by, nondomestic issuers in Rule $144 \mathrm{~A}$ equity offerings compared to equity offerings on a U.S. securities exchange for the period 1996 through September 30, 2007:

\section{Chart 1B ${ }^{20}$}

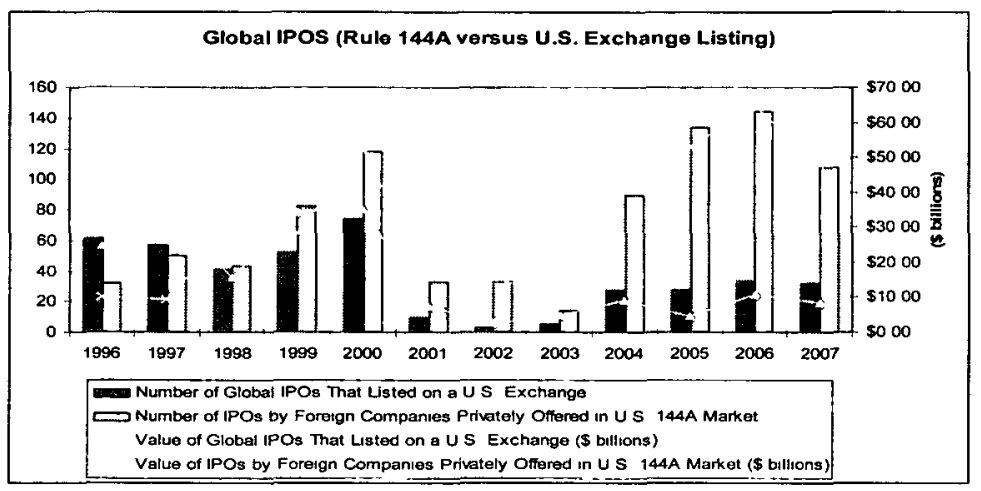

Chart IB shows that in 2006, non-U.S. issuers engaged in initial public offerings raised $\$ 64.7$ billion in the U.S. private equity market through Rule $144 \mathrm{~A}$ equity offerings, compared to only $\$ 10.8$ billion in the U.S. public equity market. ${ }^{21}$ This disparity is one also present in the U.S. debt market, a place where offering activity has principally occurred in the private market.

18. These amounts were in millions (rounded to nearest whole dollar amount): $\$ 33,512(2000)$, $\$ 62,578$ (2001), $\$ 23,259$ (2002), \$66,710 (2003), \$31,023 (2004), \$24,714 (2005), \$52,965 (2006), and $\$ 49,280$ (2007). Dealogic Database, U.S. Issuers Issuing Under 144A (search data on file with author).

19. Id. $\$ 49.280$ billion of all $144 \mathrm{~A}$ issuances in 2007 was debt convertible into equity, $\$ 4.532$ billion was equity issued prior to the company's initial public offering and $\$ 2.576$ billion was in private equity issuances without an accompanying initial public offering. $I d$

20. Dealogic Database, Rule 144A (search data on file with author). Data for 2007 through September 30, 2007.

21. Id.; see also INTERIM CAPITAL MARKETS REPORT, supra note 10, at $\mathrm{x}$. In particular, in 2006 global initial public offerings in the United States made via the Rule 144A exemption amounted to $85.7 \%$ of the U.S. value of all global initial public offerings compared to $28.96 \%$ in 1996. See COMM. ON CAPITAl MKTS. Regulation, The COMPETITIVE Position of The U.S. PUBLIC EQUITY MARKET 2 (2007), available at http:/www.capmktsreg.org/pdfs/ The_Competitive_Position_of_The_US_Public_Equity_Market.pdf [hereinafter PUBLIC EQUITY MARKET REPORT]. 
In 2007, non-domestic issuers raised $\$ 51.634$ billion in Rule 144A debt offerings compared to only $\$ 7.13$ billion on the public market. ${ }^{22}$

This private offering activity occurs largely outside the strictures of the Securities Act and beyond the SEC's supervision. Moreover, both domestic and non-domestic issuers can utilize exemptions to side-step the on-going reporting requirements of the Securities Exchange Act of 1934, as amended (Exchange Act) after a Rule 144A offering. For example, if a domestic issuer does not make a registered offering of securities, the periodic reporting regime under the Exchange Act is only triggered for a domestic issuer once it has more than $\$ 10$ million in assets and a class of equity securities held by more than 500 holders of record. ${ }^{23}$ For non-U.S. issuers, Rule $12 \mathrm{~g} 3-2 \mathrm{~b}$ of the Exchange Act provides an exemption to the Exchange Act reporting requirements. ${ }^{24} \mathrm{~A}$ non-domestic issuer who elects to furnish to the SEC certain information that it is otherwise required to file with its home regulator, and whose security is not listed or quoted on a U.S. market, is also exempt from the reporting requirements of the Exchange Act. ${ }^{25}$

The result of these exemptions is the emergence of a private, or "shadow," securities market in the United States. It is a market increasingly competitive with the public one. As it grows in size, networks are being established to capture greater public offering activity. For example, on November 12, 2007, twelve investment banks and the Nasdaq announced the creation of a private equity securities trading platform, Portal Alliance, for the listing and trading of equity securities offered under Rule $144 \mathrm{~A}^{26}$ Portal Alliance is a combination of four private securities-trading markets previously established by these banks and Nasdaq, and includes the GSTrUE market. ${ }^{27}$ The private listings markets are about to be consolidated

22. See Dealogic Database, Non-U.S. SEC Registered Debt \& Non-U.S. 144A Debt (search data on file with author). See generally Susan Chaplinsky \& Latha Ramchand, The Impact of SEC Rule $144 \mathrm{~A}$ on Corporate Debt Issuance by International Firms, 77 J. BUS. 1073 (2004) (describing the structure and practices of issuers in Rule 144A debt issuances).

23. 15 U.S.C. $\S 78 \mathrm{l}(\mathrm{g})(2006)$ (500 shareholder requirement); 17 C.F.R. $\S 240.12 \mathrm{~g}-1$ (2007) (\$10 million in assets requirement).

24. 17 C.F.R. $\$ 240.12 \mathrm{~g} 3-2(\mathrm{~b})(1)$.

25. Id. Generally, these exemptions are most relevant and utilized with respect to equity issuances. Historically, and for regulatory reasons related primarily to sales to insurance companies, issuers offering debt securities have typically registered their securities with the SEC after the offering in a process commonly known as an Exxon Capital or A/B exchange. But, in the new millennium this practice may be declining. One study has found that, at least in the private equity context, there has been an increase in the number of small- and medium-sized issuers choosing not to have a follow-on registration after a high-yield Rule 144A debt offering. See Robert P. Bartlett, III, Going Private But Staying Public: Reexamining the Effect of SarbanesOxley on Firms ' Going-Private Decisions 5 (Univ. Ga. Sch. of Law, Research Paper Series, Paper No. 08-003, 2008), available at http://ssm.com/abstract $=1088830$.

26. Press Release, NASDAQ, The PORTAL Alliance to Create Industry-Standard Facility for 144A Equity Securities (Nov. 12, 2007), available at http://www.nasdaq.com/Newsroom/ news/newsroomnewsheadlines.aspx?year $=2007$.

27. See Reuters, 12 Firms Unite for Trading in Unregistered Securities, N.Y. TIMES, Nov. 13, 2007 , at $\mathrm{C} 6$. 
into a single entity, increasing liquidity and mass for this potential trading market. And while this market is still very much in its infancy, its goal is to become a significant and active trading platform for equity securities offered under Rule $144 \mathrm{~A} .^{28}$ If it succeeds, it would create the first complete and active private equity securities market in the United States. It will also be a market largely outside the regulatory purview of the SEC and beyond the investing reach of retail investors.

\section{Non-U.S. Markets}

The growth of an alternative, private U.S. securities market is paralleled by a similar development in the international markets. The domestic markets of countries in both Asia and Europe are becoming more liquid and sizable, increasingly providing credible non-U.S. offering and listing options. For example, as of December 31, 2007, the aggregate domestic market capitalization of all European Union stock markets and the Swiss Exchange combined was $\$ 17.032$ trillion, a figure comparable to the aggregate, combined market capitalization of $\$ 19.665$ trillion for the NYSE and Nasdaq. ${ }^{29}$ Moreover, in 2007 the European Union accounted for $30.334 \%$ of aggregate world equity trading activity ${ }^{30}$ Leveraging on this strength, these non-U.S. markets have captured an increasing share of the global market for capital. In 2006, 381 issuers issued equity outside of their domestic markets. ${ }^{31}$ They raised an approximate total of $\$ 162.5$ billion, of which only $6.6 \%$, or $\$ 10.8$ billion, was obtained through a listing on a U.S. exchange. ${ }^{32}$ This is a marked decline from 2000 when approximately $36.8 \%$ of capital raised on the global market was raised through a listing on a U.S. exchange. ${ }^{33}$ Chart $1 \mathrm{C}$ compares the total proceeds raised in initial public and secondary offerings on the NYSE, Nasdaq and the American Stock Exchange with the Main Market of London Stock Exchange (LSE), its Alternative Investment Market (AIM) and all other member exchanges of

28. See Press Release, NASDAQ, supra note 26.

29. See World Federation of Exchanges, Domestic Market Capitalization, http:/www.worldexchanges.org/WFE/home.asp?menu=396\&document=4645 (last visited Mar. 10, 2008).

30. The NYSE and NASDAQ accounted for $44.35 \%$ of world equity trading activity during such period. I measure trading activity by aggregate value of trading. Calculations by author based on data obtained from World Federation of Exchanges, Value of Share Trading, http://www.world-exchanges.org/WFE/home.asp?menu=396\&document=4642 (last visited Mar. 10,2008 ). In addition, the share velocity of the London Stock Exchange during that month was $154.2 \%$ compared to $167.1 \%$ on the NYSE. World Federation of Exchanges, Share Turnover Velocity, http:/www.world-exchanges.org/WFE/home.asp?menu=396\&document=4631 (last visited Mar. 10, 2008).

31. See PUBLIC EQUITY MARKET REPORT, supra note 21, at 14 tbl.4. For these purposes these offerings are defined as a listing in their home country and a listing abroad, or a capital-raising via Rule $144 \mathrm{~A}$ in the United States. See id. at 12.

32. Id. at 14 tbl. 4 .

33. Id. The U.S. share of global capital raised increases to approximately $46.5 \%$ if capital raised through Rule 144A offerings is included. 
the World Federation of Exchanges during the period from 2002 through October $31,2007 . .^{34}$

\section{Chart 1C}

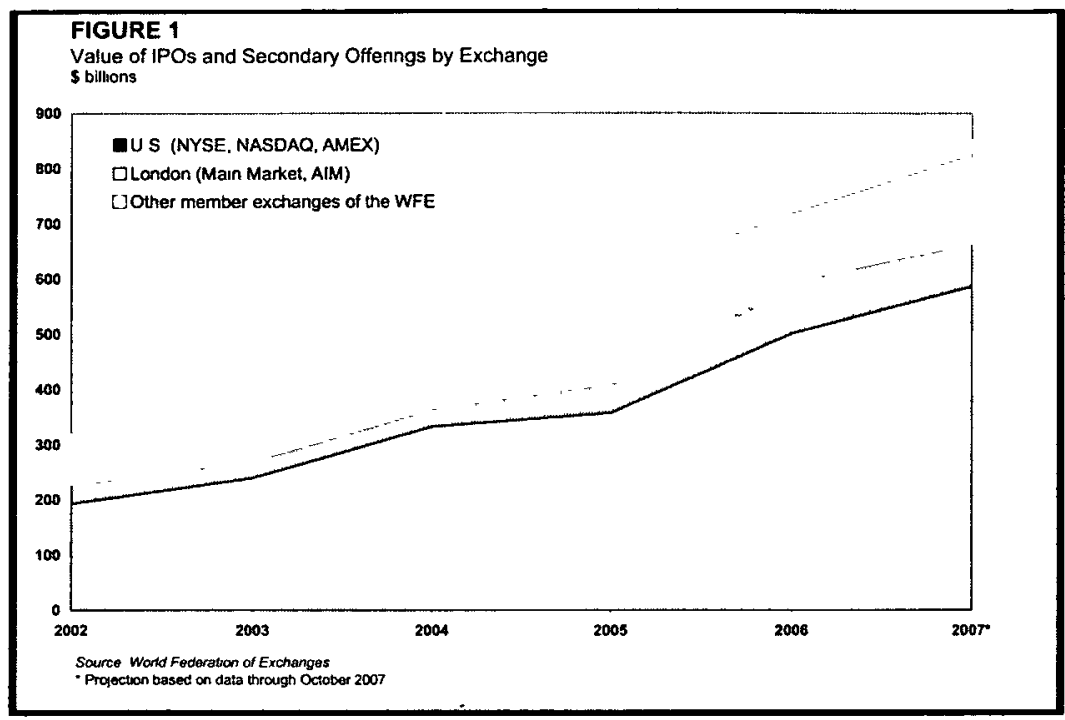

The London and the Chinese markets in particular offer a strong competitive alternative to the United States market. In 2007, equity issuers raised $\$ 82.421$ billion on the LSE and the AIM, and $\$ 158$ billion on the Hong Kong and Shanghai Stock Exchanges..$^{35}$ The strength of the Chinese market depends solely on its torrent of domestic offerings, ${ }^{36}$ but the London markets are a strong competitor to the United States for non-domestic listings. As of November 30, 2007, 682, or $21.9 \%$, of the companies listed on the LSE and AIM were non-domestic issuers. ${ }^{37}$ Additionally, in 2007, thirty-one non-domestic issuers made initial public offerings on the LSE, raising approximately $\$ 22.841$ billion in capital compared to the approximate $\$ 12.466$ billion raised by fifty-two non-domestic issuers on the

34. This chart was taken from PUBLIC EQUTTY MARKET REPORT, supra note 21 , at 6.

35. See World Federation of Exchanges, Investment Flows, http://www.worldexchanges.org/WFE/home.asp?menu=396\&document $=4635$ (last visited Mar. 9, 2008).

36. See James T. Areddy, Fear and Hope Rise With China's Stocks-Market Frenzy Nurtures New Investors and Firms, WALL ST. J., Oct. 16, 2007, at Al (stating for 2007, "Chinese stocks have nearly sextupled in value in just two years .... This year, China's markets have had the world's highest volume of shares traded, and are on track to raise the most money of any exchanges through stock offerings").

37. Specifically, 342 non-domestic issuers were listed on the LSE and 340 non-domestic issuers were listed on the AIM. See London Stock Exchange, Main Market Fact Sheet (Dec. 2007), http://www.londonstockexchange.com/NR/rdonlyres/3456A612-31 F8-480D-9039781 BFF5E3323/0/MainMarketStatistics0712.xls (click tab "Summary"); London Stock Exchange, AIM Market Fact Sheet (Nov. 2007), http://www.londonstockexchange.com/NR/rdonlyres/ BB2C9381-9445-4F05-8DF5-2CD006ADB84E/0/AIMMarketStatistics0711.xls (click tab "AIM since launch"). 
NYSE and Nasdaq combined. ${ }^{38} \mathrm{~A}$ recent study found that, in the wake of the Sarbanes-Oxley Act and the increased regulatory burden and costs it imposes, this growth in non-domestic listings on the London markets has accelerated as issuers choose to list on the LSE or AIM rather than a U.S. stock market. ${ }^{39}$

The rise in non-domestic listings on non-U.S. markets has important implications for the U.S. market. The flow of international capital and listings signifies the competitiveness of the United States in the global market. ${ }^{40}$ If the United States no longer attracts its historical proportionate share of listings and capital-raising it is a possible sign of its decreased global competitiveness. ${ }^{41}$ Moreover, these non-U.S. markets, particularly the LSE, are likely to continue to gain traction and build mass and volume as their domestic capital markets continue to grow. The recent spate of global stock exchange consolidation is only likely to compound this effect, as stock markets offer similar trading technology in different regulatory markets, thereby enhancing issuer portability. ${ }^{42}$ This directly implicates the regulatory calculus of the SEC: if issuers have viable choices outside the United States, U.S. regulation, even to the extent it increases social utility on an aggregate domestic basis, can substantially and adversely impact the United States' ability to compete in the global market for capital and listings.

\section{B. INTERMEDIATION AND DERETAILIZATION}

A second phenomenon substantially affecting the U.S. capital market is the growing intermediation of investing. ${ }^{43}$ The rise of mutual funds, pension

38. See Dealogic Database, Non-U.S. Issuers Offering Stock on NASDAQ, NYSE, AMEX, Nasdaq OTC (search data on file with author); London Stock Exchange, Main Market: Market Statistics, at 4 tbl.2 (Dec. 2007), http://www.londonstockexchange.com/NR/rdonlyres/F116BA6EE79A-42A6-8951-27EACC3C684B/0/Main MarketStatistics0712.pdf (U.K. pounds converted to U.S. dollars at $\$ 1=£ 0.504$ ).

39. See Joseph D. Piotroski \& Suraj Srinivasan, The Sarbanes-Oxley Act and the Flow of International Listings (Apr. 2007) (unpublished manuscript, available at http://ssrn.com/abstract=956987) (finding strong evidence that U.S. stock markets have experienced a decrease in the frequency of non-U.S. listings post-Sarbanes-Oxley).

40. While many argue that the U.S. is in competitive decline, the evidence is more nuanced, and at least part of this appears to be based on the increasing strength of alternative markets and the tendency of their domestic issuers to list there, rather than a decline in the United States ability to attract capital and listings. See Steven M. Davidoff, Regulating Listings in a Global Market, 86 N.C. L. REV. 89, 148-52 (2007).

41. For a full discussion of this competitive threat, see INTERIM CAPITAL MARKETS REPORT, supra note 10.

42. The reason is that portable technology provides similar execution and trading services in differing regulatory jurisdictions. Such technology is important because it underpins stock market liquidity, a significant factor in the issuer choice of where to list. See Chris J. Brummer, Stock Exchanges and the New Market for Securities Laws, 75 U. CHI. L. REV. (forthcoming 2008), available at http://ssrn.com/abstract $=1014683$.

43. Intermediaries, as the term is used in this essay, means investment pools that receive funds for investment from retail and other investors and invest such funds on behalf of these investors. 
funds and other intermediary institutional investors has transformed the investing behavior of retail investors. These investors increasingly eschew or are effectively closed off from direct purchase of securities and instead invest through intermediaries. ${ }^{44}$ This "deretailization" trend is most prominently illustrated by the extraordinary growth of the mutual fund industry. Chart 1D sets forth the number of domestic mutual funds and their aggregate assets under management for the period 1990 through $2006 .{ }^{45}$

\section{Chart 1D}

Growth of Mutual Funds (1990-2006)

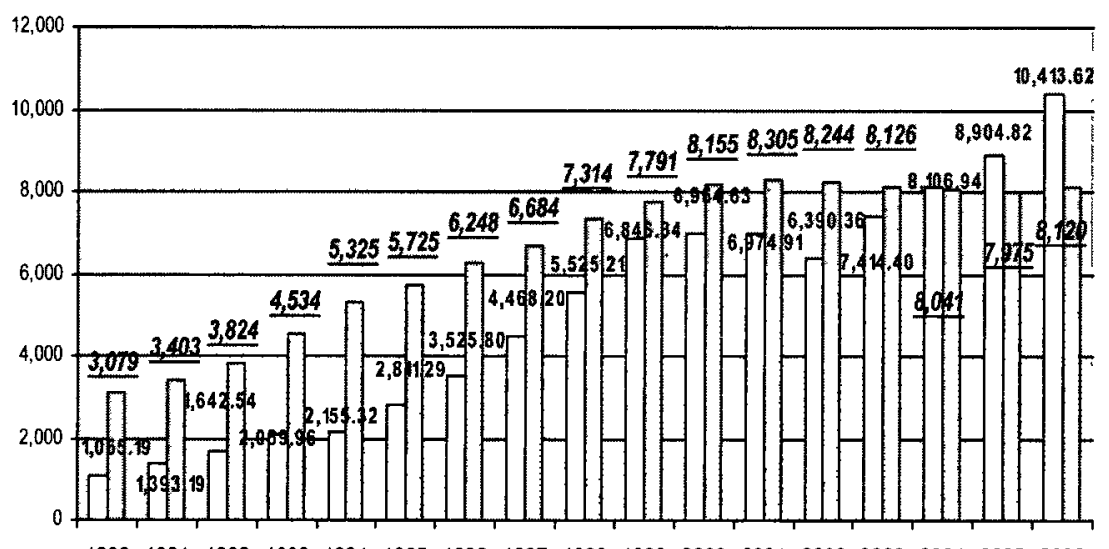

19901991199219931994199519961997199819992000200120022003200420052006

$\square$ Total Net Assets (\$ bilions) a Number of Funds

The aggregate assets under management of mutual funds have increased at an annual rate of $14.35 \%$ during this time period. And as of December 31,2006 , the assets under management of domestic mutual funds comprised $54 \%$ of the combined aggregate market capitalization of the NYSE and Nasdaq. ${ }^{46}$ A popular perception is that the rise in mutual fund holdings is the product of increased utilization by investors of defined contribution plans, such as IRA and $401(\mathrm{k}) \mathrm{s}$, and the mutual fund

44. See generally Jeff D. Opdyke, Funds Tout Access to Top Managers-Manager of Managers ' Funds Lure Record Sums as They Increasingly Target Individual Investors, WALL ST. J., June 15, 2005, at D1.

45. See INV. Co. INST., 2007 INVESTMENT COMPANY FACT BOOK 93 tbl.1 (2007), available at http://www.icifactbook.org/pdf/07_fb_table01.pdf.

46. Id. The combined NYSE and NASDAQ 2006 market capitalization of $\$ 19,286$ trillion was obtained from WORLD FEDERATION OF EXCHANGES, DOMESTIC MARKET CAPITALIZATION (2007), available at http://www.world-exchanges.org/publications/EQUITY106.pdf. 
investment they engender. ${ }^{47}$ The rise in mutual fund holdings, though, is a market-wide development. A 2007 survey of households by the Investment Company Institute found that $43.6 \%$ of U.S. households owned mutual funds. ${ }^{48}$ The survey estimated that $18.9 \%$ of U.S. households held domestic mutual fund holdings outside of a retirement plan account. ${ }^{49}$

Similar investing intermediation through defined benefit plans, commonly known as pension funds, has accompanied the rise of mutual funds. Chart $1 \mathrm{E}$ sets forth the aggregate amount invested in U.S. pension funds for the period 1999 through September 30, 2007. ${ }^{50}$

\section{Chart 1E}

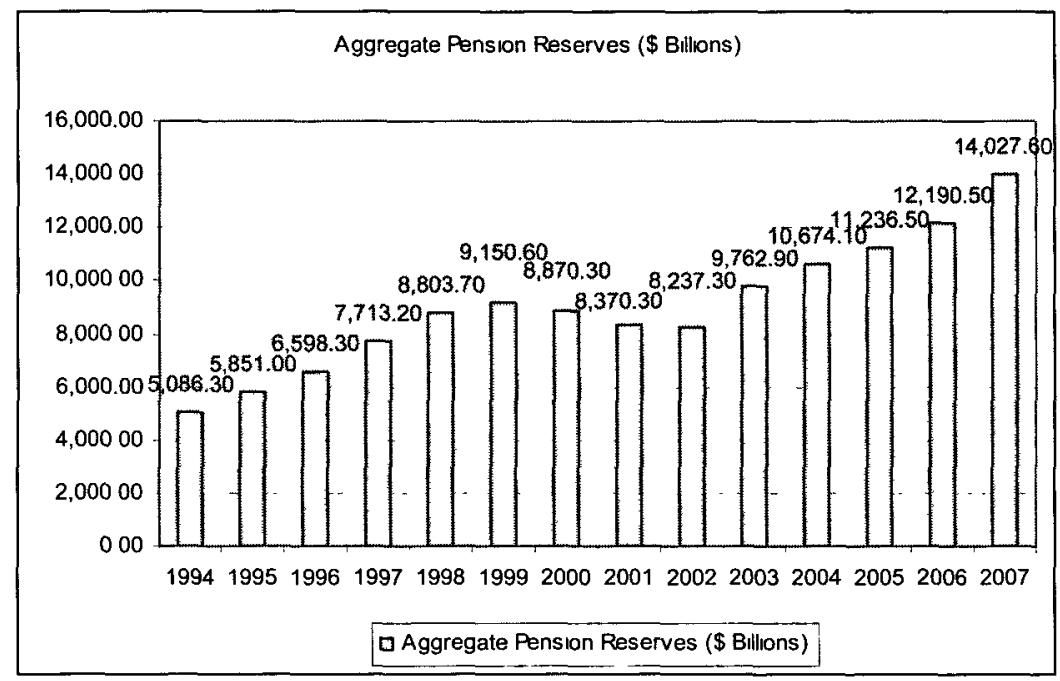

A separate investment intermediation trend among private, sophisticated investors has mimicked the spectacular rise in public investment in mutual funds and pension funds. These investors can and do invest in mutual funds, but also have the ability to invest in capital pools generally unavailable to public investors, such as hedge funds and private equity. Chart $1 \mathrm{~F}$ sets forth the aggregate amount invested globally in hedge funds for the period 1990 through $2006 .^{51}$

47. See InV. Co. Inst., TRENDS In OWNERShip OF MUTUAL FUNDS In THE UNITED STATES 6 (2007), available at http://www.ici.org/statements/res/fm-v16n5.pdf.

48. $I d$. at 3 .

49. Id. at 11 .

50. See Federal Reserve Statistical Release, Flow of Funds Accounts of the United States (Dec. 6, 2007), available at http://www.federalreserve.gov/RELEASES/zl/Current/zl.pdf. These figures combine private insured pension reserves, private noninsured pension reserves and government insurance and pension reserves. Another significant related type of intermediate investing occurs through private life insurance reserve funds. As of September 30, 2007, these intermed1ary investments amounted to $\$ 1,159.30$ billion. Id. at 61 tbl.L10.

51. Och-Ziff Capital Management Group LLC, Registration Statement (Form S-1), at 123 (July 2, 2007) [hereınafter Och-Ziff Registration Statement]. 


\section{Chart 1F}

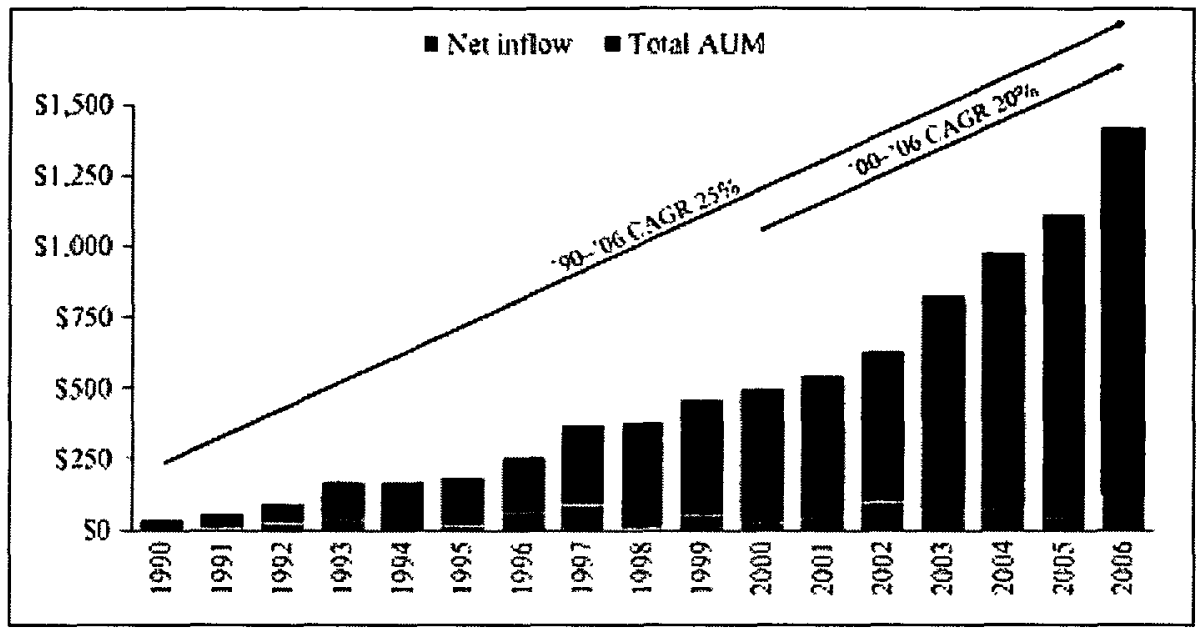

Historical Hedge Fund Assets Under Management and Net Asset Flows (\$ billions) (Source: HFR Industry Reports HFR Inc. 2007)

Pension funds and other intermediaries are also significant investors in hedge funds and other private capital pools such as private equity funds. ${ }^{52}$ This investment is often also intermediated through funds-of-funds-funds created to invest in other hedge funds or private equity funds. ${ }^{53}$ Individual, sophisticated investors often do not meet the minimum investment qualifications for a hedge fund or private equity fund, and therefore also invest in funds-of-funds with lower investment requirements. ${ }^{54}$ Hedge funds-of-funds likely comprise more than half of the invested capital in hedge funds, and as of year-end 2007 it was estimated that globally, hedge funds-of-funds with greater than $\$ 1$ billion in assets under management held approximately $\$ 1.1$ trillion in assets. ${ }^{55}$

The source of investment and investors for each of these intermediaries is different. However, their dominant presence in the U.S. capital markets spells a secular trend of deretailization and the diminishing relevance of the retail investor. Public securities are now increasingly held through intermediaries and other private funds, such as endowment and sovereign

52. See Deborah Solomon, Congress May Let Hedge Funds Manage More Pension Money, WALL ST. J., July 28, 2006, at A1.

53. See Richard K. Lai, Why Funds of Funds? 5-8 (Feb. 15, 2006) (unpublished manuscript, available at http://ssm.com/abstract=676999) (examining the financial and economic incentives engendering the utilization of funds of funds); see also Anne Tergesen, The Manic Market: An Investor's Guide: As Hedge Funds Grow, Their Walls Don't Look So High, N.Y. TIMES, Nov. 2, 1997, at C11 (reporting that sophisticated investors with lower net worth often invest in funds of funds because they "often have lower minimums than other funds do").

54. See Tergesen, supra note 53.

55. See Fund of Hedge Funds Assets Grew by One-Third in 2007, Says Survey, HEDGEWEEK.COM, Feb. 12, 2008, h九t://www.hedgeweek.com/articles/detail.jsp?content_id= 243020\&livehome=true. 
wealth funds, rather than by retail investors. As a result, one recent study found that retail investors, who once owned more than $90 \%$ of publicly traded equity, now own less than $30 \%{ }^{56}$ Retail investors are simply no longer the mainstay of the public markets and are unlikely to return to this position.

The dominance of private, sophisticated investors over the securities markets affects capital flows in the securities offering market. First, the rise of the Rule 144A market ${ }^{57}$ is in part due to the increased number of intermediaries available to purchase securities in this market. More generally, these intermediaries provide a significant source of capital outside the public securities offering process. Second, the greater resources available to these intermediaries can reduce agency costs to the extent these intermediaries provide a gatekeeper function and otherwise agitate for corporate value creation. ${ }^{58}$ Finally, greater intermediary investment should theoretically lead to reduced market volatility and speculation as investing decisions shift from retail investors who do not generally have the professional investment skill to intermediaries with such talent. ${ }^{59}$

Each intermediary type also has unique, consequential effects on the market. For example, private equity offers public companies an option to exit the public markets entirely; subsequent capital requirements for the company can also be met in the private markets through other intermediaries or financial institutions, placing the company largely outside the purview of the federal securities laws and SEC oversight. ${ }^{60}$ Hedge fund trading provides deep liquidity to both the equity and the derivatives markets. ${ }^{61}$ Hedge funds also often serve as activist investors and counterparties in highly complex financial transactions, which other regulated financial entities, such as banks, may lack the ability to do. ${ }^{62}$ Meanwhile,

56. See Cartwright Speech, supra note 9.

57. See discussion supra Part I.A.

58. See generally Bernard Black, Agents Watching Agents: The Promise of Institutional Voice, 39 UCLA L. REV. 811 (1992). But see Stephen M. Bainbridge, Shareholder Activism and Institutional Investors (UCLA Sch. of Law, Law and Economics Research Paper Series, Paper No. 05-20, 2005), available at http://ssrn.com/abstract=796227. As Professor Bainbridge notes, this potential is far from realized at this date.

59. Cf. Ramin Baghai-Wadji \& Stefan Klocker, Performance and Style Shifts in the Hedge Fund Industry 3-4 (Feb. 27, 2007) (unpublished manuscript, avalable at http://ssrn.com/abstract=920444) (finding hedge funds with poor performance improved their returns in subsequent periods after changes in investment style).

60. See Brian Cheffins \& John Armour, The Eclipse of Private Equity (European Corporate Governance Inst., Law Working Paper No. 82/2007, 2007), available at http://ssrn.com/abstract $=982114$.

61. See Timothy F. Geithner, Keynote Address at the National Conference on the Securities Industry: Hedge Funds and Their Implications for the Financial System (Nov. 17, 2004), available at http://www.newyorkfed.org/newsevents/speeches/2004/gei041117.html.

62. See, e.g., William W. Bratton, Hedge Funds and Governance Targets, 95 GEO. L.J. 1375, 1427 (2007) (finding that hedge fund shareholder interventions "neither amount to near-term holdups nor revive the 1980s leveraged restructuring"); Alon Brav et al., Hedge Fund Activism, Corporate Governance, and Firm Performance (Vanderbilt Univ., Law and Economics Research 
pension funds have been accused of making investment decisions based on inappropriate political considerations to the possible detriment of their beneficiaries. ${ }^{63}$

The presence of these intermediaries and their effect on the capital markets shift the calculus for securities regulation. The Securities Act and the Exchange Act are designed to protect retail investors. ${ }^{64}$ Yet, if sophisticated intermediaries now undertake the bulk of investing, the protections of these Acts become procedural, and the opportunities for deregulation increase. More specifically, if investors in public offerings and public securities are largely sophisticated intermediaries, the protections required by the federal securities laws can arguably be left in some measure to private bargaining, with intermediaries serving as agents for the public investor stub, if any. ${ }^{65}$ In these circumstances, compliance with the federal securities laws becomes, to some extent, an unnecessary transaction cost. ${ }^{66}$ Intermediaries also provide a strong alternative supply of private capital to issuers who wish to avoid the costs associated with registration, the scrutiny of the public offering process generally, and on-going public reporting obligations. As the private securities market develops further, these intermediaries and the structures created to accommodate them, and the private offering market generally, create a more viable alternative to an offering on the U.S. public markets. ${ }^{67}$ Finally, these intermediaries create

Paper No. 07-28, 2007), available at http://ssrn.com/abstract $=948907$ (examining a dataset of hedge fund activism in the United States during the period 2001 through 2005 and finding that hedge funds act as value investors and shareholder advocates). Hedge fund innovation may have a down-side though: increasing complexity and systematic risk. See generally RICHARD BoOkstaber, A DEMON OF OUR OWN DEsign: MARKETS, Hedge Funds AND THE PERILS OF FINANCIAL INNOVATION (2007).

63. See Roberta Romano, Public Pension Fund Activism in Corporate Governance Reconsidered, 93 ColuM. L. REV. 795 (1993); Stewart J. Schwab \& Randall S. Thomas, Realigning Corporate Governance: Shareholder Activism by Labor Unions, 96 MICH. L. REV. 1018 (1998). But see Gordon L. Clark \& Tessa M. Hebb, Pension Fund Corporate Engagement The Fifth Stage of Capitalism, 59 RELATIONS INDUSTRIELLES 192 (2004).

64. 15 U.S.C.A. $\S 77 \mathrm{~b}(\mathrm{~b})(2006)$.

Whenever pursuant to this subchapter the Commission is engaged in rulemaking and is required to consider or determine whether an action is necessary or appropriate in the public interest, the Commission shall also consider, in addition to the protection of investors, whether the action will promote efficiency, competition, and capital formation.

Id.

65. However, such laws may still provide value in maintaining investor confidence and preventing rent-seeking by these agents themselves. See generally Frank B. Cross \& Robert A. Prentice, The Economic Value of Securities Regulation, 28 CARDOZO L. REV. 333 (2006) (examining the positive effects of regulation on stock markets).

66. While theoretically feasible, political realities and the SEC focus on its core mission of protecting the public investor may prevent any such deregulation.

67. Issuers, though, may still be incentivized to maintain a public listing of their securities, since regulatory restrictions may limit the extent to which an intermediary may invest in nonpublic or illiquid securities. For example, the Investment Company Act stipulates that generally an 
regulatory-supervision concerns. Mutual funds are subject to direct supervision by the SEC under the Investment Company Act of 1940 (Investment Company Act) ${ }^{68}$ but hedge funds in part exist outside the regulatory purview of the SEC, ${ }^{69}$ while pension funds are regulated by the Department of Labor, ${ }^{70}$ and other private capital pools, such as endowment funds and sovereign wealth funds, are largely unregulated. ${ }^{71}$ The consequence is, not only is a significant portion of the U.S. capital market increasingly outside the federal securities laws, but many influential market investors that raise their own unique issues also exist apart from SEC oversight. ${ }^{72}$ The ability of the SEC to effectively regulate the securities markets is correspondingly made more difficult.

\section{MARKET INNOVATION AND SOPHISTICATION}

Capital markets are increasingly sophisticated and complex due to the quickening pace of financial innovation. Rapid advances in finance, both structural and theoretical, have enhanced the capacity of market participants to create and price financial products. ${ }^{73}$ Market actors consequently have increased ability and latitude to allocate risk and corporate capital. This investing model provides differing, more viable avenues for raising capital in alternative markets and financial products, and it is causing a rethink of previous assumptions and practices concerning an issuer's need to access the public equity markets. It has also created a host of new issues for

open-ended investment company may not hold fifteen percent or more of its assets in illiquid securities. See Revisions of Guidelines to Form N-1A, Investment Company Act Release No. 18,612, [1991-1992 Transfer Binder] Fed. Sec. L. Rep. (CCH) \ 84,930, at 82,477 (Mar. 12, 1992). A security is considered "illiquid" if a fund is unable to promptly sell or dispose of the security in the ordinary course of business at its current value within seven days. 15 U.S.C.A. $\S$ 80a-59(b) (2006); see Acquisition and Valuation of Certain Portfolio Instruments by Registered Investment Companies, Exchange Act Release No. 14,983, [1985-1986 Transfer Binder] Fed. Sec. L. Rep. (CCH) ๆ 83,972 (Mar. 21, 1986). Alternative stock markets, such as Portal Alliance, are an important predicate to creating such an alternative market because if they succeed they can provide a private alternative source of liquidity engendering a more complete market. See supra notes $26-28$ and accompanying text.

68. 15 U.S.C.A. $\$ \S 80 \mathrm{a}-1$ to $-64(2006)$.

69. See Registration Under the Advisers Act of Certain Hedge Fund Advisers, Investment Advisers Act Release No. 2333, 69 Fed. Reg. 72,054 (Dec. 10, 2004) [hereinafter Adviser Registration Adopting Release].

70. See 29 C.F.R. § 2530 (2007).

71. Sovereign wealth funds in particular raise their own national security and investing efficiency issues. See, e.g., Steven R. Weisman, A Fear of Foreign Investments, N.Y. TIMES, Aug. 21, 2007, at C1; Steven M. Davidoff, Telling Friend From Foe in Sovereign Investments, DEALBOOK, Apr. 2, 2008, http://dealbook.blogs.nytımes.com/2008/04/02/telling-friend-from-foein-foreign-investments/.

72. These investors are still subject to the general requirements of the federal securities laws. The question is whether their influence, size and nature warrant particular oversight.

73. See Eleanor Laise, Mutual Funds Add Exotic Fare to the Mix-Many Are Making Increasing Use of Complex Derivatives to Enhance Performance, but the Strategies Carry Risks, WALL ST. J., Apr. 4, 2007, at D1 (discussing the increasing use of complex financial products by mutual funds). 
regulators grappling with the complexity and rapid, innovative development of these products. ${ }^{74}$

The rise of the U.S. derivatives market is a primary example of these advances. As of June 30,2007, the aggregate notional value of derivatives in the United States was $\$ 347.1$ trillion, compared to $\$ 865.6$ billion in $1987 .{ }^{75}$ This is a market that exists due to the efforts of a core group of academics and financial professionals who invented the mathematical arsenal to price and structure these derivatives. ${ }^{76}$ The U.S. derivatives market is increasingly flexible and complex: It consists of not just forwards, futures, and options on equities and commodities, but derivatives are now priced and issued on a variety of more sophisticated and harder-to-price assets and events, such as property and weather. ${ }^{77}$ The credit derivative market, which consists of products designed to allocate credit risk and lubricate credit markets, has become a particularly valuable component of the U.S. capital market. As the products increase in variety and complexity, they increase the ability of financial institutions to extend credit. ${ }^{78}$ As of June 30,2007 , there was $\$ 45,464.50$ billion in outstanding credit default swaps, compared to $\$ 631.50$ billion as of June $30,2001 .^{79}$ This is an annual growth rate of $100 \%$.

More tellingly, these products and markets have the potential to lessen the need for issuers to access the public equity markets. The use of derivatives for hedging purposes can stabilize capital flows and make credit or other alternative capital a more viable source for funding needs against the transaction and other costs associated with public equity. As Professors Ronald Gilson and Charles Whitehead have recently theorized, financial alchemy may now be sufficiently advanced to structure and discretely

74. This essay focuses on these issues in the context of capital-raising. But the new capital markets paradigm is allowing actors to use derivatives to perhaps unduly affect corporate takeovers and proxy votes under the radar of historical SEC requirements. See Andrew Ross Sorkin, A Loophole Lets a Foot in the Door, N.Y. TIMES, Jan. 15, 2008, at C1; see also Henry T. C. Hu \& Bernard Black, The New Vote Buying: Empty Voting and Hidden (Morphable) Ownership, 79 S. CAL. L. REV. 811 (2006).

75. International Swaps and Derivatives Association, ISDA Market Survey Results, http://www.1sda.org/statistics/pdf/ISDA-Market-Survey-historical-data.pdf (last visited July 31, 2007) [hereinafter ISDA Market Survey Results].

76. For a good history see PERRY MEHRLING, FISCHER BLACK AND THE REVOLUTIONARY IDEA OF FINANCE (2005).

77. For example, the S\&P/Case-Shiller Home Price Indices measure changes in the value of the U.S. residential real estate market (on a weighted composite index), as well as in ten specific metropolitan regions across the United States. Futures contracts based on these indices are traded on the CME Group derivatives exchange. See CME GROUP, S\&P/CASE-SHILLER HOME PRICE INDICES FUTURES AND OPTIONS: INTRODUCTORY GUIDE 3 (2007), available at http://www.cme.com/files/cmehousing_brochure.pdf.

78. See Donald L. Kohn, Vice Chairman, Fed. Reserve Bd. of Governors, Remarks at the Conference on Credit Risk and Credit Derivatives: Asset-Pricing Puzzles, Credit Risk, and Credit Derivatives (Mar. 22, 2007), available at http://www.federalreserve.gov/newsevents/speech/ kohn20070322a.htm.

79. ISDA Market Survey Results, supra note 75. 
separate issuer risk such that public equity capital is no longer necessary or desirable in many circumstances. ${ }^{80}$ Public equity may lose its historical place as the lowest-cost risk-bearer in light of derivative market alternatives. ${ }^{81}$ Professors Gilson and Whitehead ultimately attribute the rise of the private equity market to these developments, and predict that issuers may decreasingly access the public markets for equity capital as a result. ${ }^{82}$

The rapidity of financial innovation and the related consequences create at least four regulatory issues. ${ }^{83}$ First, these products are often difficult to regulate-their complexity and risk are hard to comprehend and dissect. ${ }^{84}$ The current sub-prime mortgage crisis and apparent mispricing of collateralized debt obligations based on these mortgage securities aptly illustrate the systemic and regulatory issues associated with more complex financial instruments. Second, to the extent federal securities regulation is rule- rather than principle-based, it is less responsive to rapid changes in the structure and nature of the capital markets. ${ }^{85}$ Moreover, there is a permanence to this gap as adaptation to new regulation is immediate due to financial innovation, but the regulatory process takes years to respond.

This innovation can also create issues that defy regulation. For example, a number of academics have recently published papers setting forth models for creation of synthetic hedge funds. ${ }^{86}$ Skillful retail investors

80. Ronald J. Gilson \& Charles K. Whitehead, Deconstructing Equity. Public Ownership, Agency Costs, and Complete Capital Markets, 108 ColuM. L. Rev. 231, 235 (2008). Professors Gilson and Whitehead echo Michael Jensen's famous article in the 1980's heralding the eclipse of the publicly traded corporation. See Michael C. Jensen, Eclipse of the Public Corporation, HARV. BUS. REV., Sept.-Oct. 1989 (rev. 1997), available at http://ssm.com/abstract=146149.

81. Financial innovation can also substitute for other public company benefits. For example, prediction markets may provide equivalent informational benefits to that of public equity markets. See Michael B. Abramowicz \& M. Todd Henderson, Prediction Markets for Corporate Governance, 82 NOTRE DAME L. REV. 1343 (2007); Saul Levmore, Simply Efficient Markets and the Role of Regulation: Lessons from the lowa Electronic Markets and the Hollywood Stock Exchange, 28 J. CORP. L. 589 (2003).

82. Gilson \& Whitehead, supra note 80, at 236; see also Larry E. Ribstein, The Rise of the Uncorporation (Univ. of Ill. Coll. of Law, Illinois Law and Economics Research Paper Series, Paper No. LE07-026, 2007), available at http://ssm.com/abstract=1003790 (discussing the implications of the increasing utilization of firms that include key partnership-type features on the future of firms and regulation of uncorporate forms).

83. The increasing information provided and understanding gained by ever-more sophisticated academic study of the capital markets also provides the SEC with greater ability to intelligently regulate markets.

84. See, e.g., Steven L. Schwartz, Rethinking the Disclosure Paradigm in a World of Complexity, 2004 U. ILL. L. REV. 1 (highlighting the increasing complexity of public disclosure and concomitant inability of investors, even sophisticated ones, to properly comprehend and analyze this information).

85. See Lawrence A. Cunningham, A Prescription to Retire the Rhetoric of "Principles-Based Systems" in Corporate Law, Securities Regulation, and Accounting, 60 VAND. L. REV. 1411, 1446-53 (2007).

86. See, e.g., Harry M. Kat \& Helder Palaro, "FUNDCREATOR": Reply to the Critics (Alt. Inv. Research Centre, Working Paper No. 0041, 2007), available at http://ssm.com/abstract=1017873; Harry M. Kat \& Helder P. Palaro, Who Needs Hedge Funds?: 
can now make investments "akin" to having actually invested in their own hedge funds. ${ }^{87}$ Yet, the SEC has adamantly maintained that hedge fund investments should be "off-limits" to public investors. ${ }^{88}$ If hedge funds are indeed too risky for retail investment, presumably virtual investments like synthetic hedge funds are as well. How does the SEC regulate to prohibit virtual investments such as a synthetic hedge fund? There is likely no way. ${ }^{89}$

Third, direct federal regulation of the U.S. securities markets is in large measure allocated between the SEC and the Commodities Futures and Trade Commission (CFTC). The CFTC generally regulates non-equity derivatives while the SEC regulates equity derivatives and securities, and each has a separate regulatory regime..$^{90}$ An informed and rational economic market actor therefore has latitude to structure publicly traded products to arbitrage between SEC or CFTC regulation, depending upon the regulatory costs imposed.$^{91}$ Moreover, the rise of derivatives generally and the CFTC's expanding domain has limited the SEC or any one regulator's ability to completely supervise the U.S. capital markets. This trend may affect the SEC particularly, as the increased ability of issuers to manage risk and capital needs through derivatives as an alternative to public equity capital increasingly deprives the SEC of jurisdiction over corporate capital raising. ${ }^{92}$

Finally, financial innovation means that the simple prohibition or confining regulation of a financial product is no longer a panacea if demand for the security continues. Creative finance professionals will simply offer substitute financial products that mimic the prohibited or restricted investment. For example, the rise in special purpose acquisition companies (SPACs) can be attributed in large part to financial innovators utilizing a

A Copula-Based Approach to Hedge Fund Return Replication (Alt. Inv. Research Centre, Working Paper No. 0027, 2005), avallable at http://ssm.com/abstract $=855424$.

87. Professors Kat and Palaro are now marketing their hedge fund replication technique, known as FundCreator, to the general public. See Fundcreator.com, http:/www.fundcreator.com/ (last visited Feb. 29, 2008).

88 See infra Part II.A.

89. See also Andrew Lo \& Pankai Patel, 130/30: The New Long-Only, at 8-13 (Dec. 11, 2007) (unpublished manuscript, avalable at $\mathrm{http} / / \mathrm{ssrn} . \mathrm{com} / \mathrm{abstract}=1074622$ ) (proposing two long-short investing index strategies showing increased benefits over a static S\&P 500 index investment).

90. See generally Roberta Romano, The Political Dynamics of Dertvative Securities Regulation, 14 YALE J. REG. 279 (1997).

91. The fractured nature of U.S. financial services regulation provides ample opportunity for arbitrage beyond that of CFTC and SEC regulation and jurisdiction; one count puts at 115 the number of state and federal agencies involved in regulating some aspect of financial services. See Elizabeth F. Brown, The Tyranny of the Multitude is a Multipled Tyranny. Is the United States Financial Regulatory Structure Undermining U.S. Competitiveness?, 2 BROOK. J. CORP. FIN. \& COM. L. (forthcoming 2008) (manuscript at 4).

92. In light of the current credit crisis, the Treasury Department has proposed merging the CFTC and SEC. See DEP'T OF THE TREASURY, BLUEPRINT FOR A MODERNIZED FINANCIAL REGULATORY STRUCTURE 11 (Mar. 2008). 
financial product to side-step prohibitory regulation on private equity funds offering their investments to the public. ${ }^{93}$

\section{SEC REGULATORY FAILURE IN THE NEW PARADIGM}

The new regulatory paradigm is one of complexity and dilemma for the SEC. Market proliferation, intermediary investing, deretailization and increased financial innovation combine with other emergent forces to create strong alternatives for raising capital. ${ }^{94}$ Issuers are no longer largely confined to the public markets for equity and other capital-raising. The SEC rule-making process is thus subject to greater competitive force. Prohibitory or unduly burdensome securities regulation will simply cause capital and capital-raising to migrate to alternative markets. Additionally, substitute financial products can now be devised to circumvent and arbitrage SEC regulation. Beyond these forces, the entire structure and content of SEC regulation is possibly in question. This is particularly true if public equity markets are entering a revolutionary transformational stage where, by definition, they are no longer the optimal place to list and raise capital, and public equity capital and listings are no longer a necessity or even desirable capital provider or lowest-cost risk-bearer. The paradigm shift is real and consequential.

Yet, the SEC has largely refused to acknowledge these developments. Instead, the SEC appears to be focused on tending the current code and regulating as it has historically, without heed to the new paradigm. The result is regulation that is increasingly inapposite and which fails to adequately account for the increased mobility and sources of capital and the changed structure of the U.S. capital markets generally. A full analysis of SEC regulatory practices and their drivers is beyond the scope of this essay. Nonetheless, the problems and tensions with recent SEC rulemaking and the effect of the new capital market paradigm can be highlighted by examining the recent SEC regulatory experience with hedge funds. ${ }^{95}$

\section{A. Hedge Fund Regulation}

In the last forty years, hedge funds have become increasingly prominent fixtures of the U.S. capital market. As of year-end 2006, it was estimated

93. "SPACS are companies organized to purchase one or more operating businesses. The equity funds to acquire these businesses come from an initial public offering by the SPAC." Steven M. Davidoff, Black Market Capital, 2008 ColuM. BuS. L. REV. (forthcoming 2008) (manuscript at 34). For a further discussion of these vehicles and the effect of SEC regulation on the demand and structure of this financial product, see $i d$.

94. See discussion supra Part I.

95. The SEC has sometimes inexplicably refused to embrace modern regulatory technique and cost-benefit analysis. See Edward Sherwin, The Cost-Benefit Analysis of Financial Regulation: Lessons from the SEC's Stalled Mutual Fund Reform Effort, 12 STAN. J.L. BUS. \& FIN. 1 (2006). 
that there were 9,462 hedge funds. ${ }^{96}$ Yet, until this millennium, SEC regulatory attention to these capital pools was, at least publicly, limited. ${ }^{97}$ Then, in 1998 the global macro hedge fund Long Term Capital Management (LTCM) spectacularly imploded. The collapse of LTCM not only resulted in a $\$ 4.6$ billion loss for its investors but imperiled the stability of the entire global capital market. ${ }^{98}$ This event unleashed a host of regulatory forces spurring the SEC to more closely scrutinize and attempt to regulate hedge funds.

In 2004, these developments culminated with SEC action. The SEC Commissioners voted 3-2 to adopt Rule 203(b)(3)-2 under the Investment Advisers Act of 1940 (Advisers Act), ${ }^{99}$ which requires almost all domestic hedge fund advisers to register with the SEC. ${ }^{100}$ New Rule 203(b)(3)-2 amended prior SEC Rule 203(b)(3), which had permitted an adviser to count each fund it advised as a client, thereby side-stepping SEC registration requirements. ${ }^{101}$ Under the amended rule, investment advisers meeting the definition of "private funds" would generally be required to look through their advised funds and count each investor, as opposed to each fund, as a client to determine whether the adviser was required to register. ${ }^{102}$ The rule required the majority of qualifying hedge fund advisers to register by February 1, 2006. ${ }^{103}$ However, on June 23, 2006 the D.C. Circuit Court of Appeals vacated and remanded the new rule, on the grounds that the SEC's "interpretation of the word 'client' comes close to violating the plain language of the statute," and was arbitrary. ${ }^{104}$

In response to the D.C. Circuit decision, the SEC abandoned its attempt to require hedge fund advisers to register under the Advisers Act. ${ }^{105}$ Instead, in 2006, the SEC proposed to tighten the restrictions on the type of investors who could invest in hedge funds. The SEC proposed that the

96. Och-Ziff Registration Statement, supra note 51, at 122 (citing Hedge Fund Research http://www.hedgefundresearch.com/). This is compared to an estimate of sixty-eight active hedge funds in 1984. FRANÇOIS-SERGE LHABITANT, HEDGE FUNDS: MYTHS AND LIMITS 8 (2002). For a detailed history of hedge funds in the United States, see $i d$. at 7-12.

97. SEC STAFF, IMPLICATIONS OF THE GROWTH OF HEDGE FUNDS, at app.A (2003), available at http://www.sec.gov/news/studies/hedgefunds0903.pdf (detalling the history of SEC review and regulation of hedge funds).

98. See Roger Lowenstein, When Genius Failed: The Rise and Fall of Long-Term CaPital MANAGEMENT (2000).

99. See Adviser Registration Adopting Release, supra note 69; see also Dissent of Commissioners Cynthia A. Glassman and Paul S. Atkins to the Registration Under the Advisers Act of Certain Hedge Fund Advisers, 69 Fed. Reg. 72,089 (Dec. 10, 2004) [hereinafter Adviser Registration Dissent].

100. 17 C.F.R. § 275.203(b)(3)-2 (2007).

101. Adviser Registration Adopting Release, supra note 69 , at 72,065-66.

102. Id at 72,070 .

103. Id. at 72,077 .

104. Goldstein v. SEC, 451 F.3d 873, 881,884 (D.C. Cir. 2006).

105. Press Release, SEC, Statement of Chairman Cox Concerning the Decision of the U.S. Court of Appeals in Phillip Goldstein et al. v. SEC (Aug. 7, 2006), available at http://www.sec.gov/news/press/2006/2006-135.htm. 
definition of accredited investor under Regulation $D$ be amended for "investment pools" (i.e., hedge funds) that rely on the Rule $3(\mathrm{c})(1)$ exemption from registration under the Investment Company Act. ${ }^{106}$ Previously, an investor need only have had an aggregate net worth of $\$ 1$ million dollars or an individual income which exceeded $\$ 200,000$ (or joint income with the person's spouse exceeding $\$ 300,000$ ) in each of the two most recent years to qualify as an accredited investor under Regulation D, and permit them to invest in a Rule 3(c)(1) hedge fund or private equity fund. ${ }^{107}$ The proposed rule would revise the definition of accredited investor so that a natural person could qualify and be allowed to invest in hedge funds only if he or she met the previous tests of net worth or income, and owned at least $\$ 2.5$ million in investments. ${ }^{108}$

These attempts by the SEC at hedge fund regulation have been criticized as both schizophrenic and irrational. ${ }^{109}$ In its first regulatory foray, the SEC attempted to address systemic issues of risk and transparency by requiring hedge fund advisers to submit to SEC oversight and regulation by registering under the Advisers Act. ${ }^{110}$ Yet, system-wide risk issues are largely the regulatory purview of the Treasury and Federal Reserve, and the latter notably opposed this regulation. ${ }^{111}$ Moreover, the

106. See Prohibition of Fraud by Advisers to Certain Pooled Investment Vehicles; Accredited Investors in Certain Private Investment Vehicles, Exchange Act Release No. 8766, [2006 Transfer Binder] Fed. Sec. L. Rep. (CCH) ๆ 87,736, at 84,047-48 (Dec. 27, 2006) [hereinafter Accredited Investor Proposing Release].

107. The individual can also have joint income with his or her spouse in excess of $\$ 300,000$ to qualify. In addition, the individual must have a reasonable expectation of reaching the same income level in the current year. Id. at 84,047. The rule is embodied in Rule 501 of the Securities Act. 17 C.F.R. $\$ 230.501$ (2007). In addition to relyıng upon the Rule 506 offering exemption within Regulation D, funds also sometimes rely upon Rule 506's statutory foundation, Section $4(2)$, for their Securities Act offering exemption. See generally Fletcher, supra note 12, at 112024 (discussing the structure of securities registration exemptions). The SEC is currently considering raising these investment thresholds. See Revisions of Limited Offering Exemptions in Regulation D, Securities Act Release No. 8828, Investment Company Act Release No. 27,922, [2007 Transfer Binder] Fed. Sec. L. Rep. (CCH) ๆ 87,939, at 85,171 (Aug. 3, 2007).

108. See Accredited Investor Proposing Release, supra note 105, at 84,048 . The SEC also proposed in this release a new antifraud rule under the Advisers Act to clarify, in light of the Goldstein decision, the SEC's ability to bring enforcement actions under the Advisers Act against investment advisers who defraud investors or prospective investors in a hedge fund or other pooled investment vehicle. Id. at 84,042-43. The SEC adopted this rule on July 11, 2007. See Prohibition of Fraud by Advisers to Certain Pooled Investment Vehicles, Investment Adviser Act Release No. 2628, [2007 Transfer Binder] Fed. Sec. L. Rep. (CCH) ף 87,937, at 85, 157 (Aug. 3, 2007).

109. See generally Troy A. Paredes, Hedge Funds and the SEC: Observations on the How and Why of Securities Regulation 20 (Wash. Univ. Sch. of Law, Faculty Working Paper Series, Working Paper No. 07-05-01, 2007), available at http://ssm.com/abstract $=984450$.

110. The SEC relied heavily on the possibility of hedge fund adviser fraud to justify its adviser registration rule. However, the SEC was only able to cite fifty-one enforcement actions for hedge fund adviser misconduct. See Adviser Registration Adopting Release, supra note 98, at 81,494.

111. See Rachel McTague, Hedge Funds: Greenspan Expresses Concern over SEC Hedge Fund Proposal, Sec. L. Daily (BNA) (Aug. 30, 2004). The SEC has also skirted this bar by arguing that small investors are now widely invested in hedge funds through intermediaries such as pension 
registration requirements the SEC sought to impose were equivalent to CFTC regulations at the time applicable to a majority of hedge funds. ${ }^{112}$

The SEC then abandoned these concerns in its latest rule proposals, instead shifting its regulatory focus to protection of investors, a core mission. ${ }^{113}$ However, the rationale of this tactical change is equally puzzling. To justify placing further restrictions on the type of investor that can invest in hedge funds, the SEC stated:

Not only do private pools often use complicated investment strategies, but there is minimal information available about them in the public domain. Accordingly, investors may not have access to the kind of information provided through our system of securities registration and therefore may find it difficult to appreciate the unique risks of these pools . . . ${ }^{114}$

Nowhere did the SEC cite a single financial or academic study about the problems or financial benefits of hedge funds to justify this statement or, indeed, the Rule itself. Instead, the SEC has steadfastly refused to contemplate public investment in hedge funds. Its regulatory approach is to further restrict public investment, justifying this action on the grounds that hedge funds are too "risky" for public investors. ${ }^{115}$ But the SEC has failed to conduct any studies or other cost-benefit analysis of public investment in hedge funds or cite any research on this issue to support its position. If they did so, they would find that there are a number of benefits to public investment in hedge funds, including the historical ability of some of these funds to earn extraordinary risk-adjusted positive returns, as compared with other investment classes and strategies. ${ }^{116}$ Other ostensible benefits include

funds, justifying its regulatory jurisdiction. See William H. Donaldson, Chairman, SEC, Remarks Before the Investment Counsel Association of America (Apr. 22, 2004), avalable at http://www.sec.gov/news/speech/spch042204whd.htm [hereinafter SEC Speech]. The SEC does have a collective voice in regulating systemic risk through the President's Working Group on Financial Markets.

112. See Adviser Registration Dissent, supra note 98, at 81,531-32. The CFTC raised strong concerns with the SEC's proposed rule on this and other grounds. See Letter from Sharon BrownHruska, Acting Chairman, U.S. Commodity Futures Trading Comm'n, to Chairman Donaldson and Commissioners of the SEC (Oct. 22, 2004), available at http://www.sec.gov/rules/ proposed/s73004/sbhruska102204.pdf.

113. 15 U.S.C.A. § 77b(b) (2006).

114. See Accredited Investor Proposing Release, supra note 105, at 84,053.

115. See, e.g., Prohibition of Fraud by Advisers to Certain Pooled Investment Vehicles, Securities Act Release No. 8766, 72 Fed. Reg. 400, at 400 (proposed Jan. 4, 2007) (proposing "a new category of accredited investor ... designed to help ensure that investors in these types of funds are capable of evaluating and bearing the risks of their investments").

116. See Roger G. Ibbotson \& Peng Chen, The A, B, Cs of Hedge Funds: Alphas, Betas, and Costs 12-13 (Yale Int'l Ctr. Fin., Working Paper No. 06-10, 2006), available at $\mathrm{http}: / / \mathrm{ssm} . \mathrm{com} / \mathrm{abstract}=733264$ (finding that hedge fund alphas were significantly positive at $3.04 \%$ in a sample of almost 3,000 hedge funds from the TASS database during the period January 1995 through April 2006); see also Daniel Capocci \& Georges Hübner, Analysis of Hedge Fund Performance. 11 J. EMPIRICAL FIN. 55 (2004); Robert Kosowski, Naryan Y. Naik \& Melvin Too, Do Hedge Funds Deliver Alpha? A Bayesian and Bootstrap Analysis, 84 J. FIN. ECON. 229 (2007); William Fung et al., Hedge Funds: Performance, Risk and Capital Formation 3 (July 
diversification, more managed risk, and the ability to leverage capital at a lower interest rate than the average investor would otherwise be capable of or have access to. ${ }^{117}$ The SEC has yet to consider or even acknowledge any of these benefits in its hedge fund rulemaking.

Professor Troy Paredes has ably written on the regulatory forces driving the SEC's hedge fund regulation and its economic failures. ${ }^{118} \mathrm{He}$ attributes SEC regulatory action to a precautionary principle approach effected by cognitive psychology and the political economy of public demand. ${ }^{119}$ SEC fears of future hedge fund collapses, possible capital markets disruption, and the investor losses these events may engender have been exacerbated by the availability heuristic. ${ }^{120}$ Consequently, the SEC has adopted a precautionary approach towards regulation of hedge funds, despite the absence of certain evidence on their risk parameter and the regulatory cost of such action. ${ }^{121}$ The SEC is also painfully aware of the public criticism it received for its inaction and failure to properly regulate and supervise the U.S. capital market in the wake of the Enron/WorldCom scandals. ${ }^{122}$ The result was congressional action in the form of the Sarbanes-Oxley Act. ${ }^{123}$ SEC regulation of hedge funds thus has a classic political-economy rationale: It creates an appearance that the SEC is proactively responding to the perceived hedge fund risk and is responsive to congressional and popular interest in hedge funds. An alternative course would likely have raised further congressional ire and resulted in adverse consequences for the SEC, such as reduced funding and prestige. ${ }^{124}$

There are also other, complementary explanations in addition to the regulatory forces Professor Paredes cites. Regulation of hedge funds comports with the SEC's aggrandizing and expansionist regulatory

2006) (unpublished manuscript, avalable at http://ssrn.com/abstract=778124). But see Henry $M$. Kat \& Joëlle Miffre, The Impact of Non-Normality Risks and Tactical Trading on Hedge Fund Alphas 4 (May 24, 2006) (unpublished manuscript, available at http://ssrn.com/abstract=424368) (analyzing prior studies of hedge fund performance and finding that they overstate hedge fund alpha on average by $1.54 \%$ ).

117. See generally Houman B. Shadab, Fending for Themselves: Regulatory Reform to Create a U.S. Hedge Fund Market for Retall Investors, 11 N.Y.U. J. LEGIS. \& PUB. POL'Y (forthcoming 2008).

118. Paredes, supra note 108; see also Troy A. Paredes, On the Decision to Regulate Hedge Funds: The SEC's Regulatory Philosophy, Style, and Mission, 2006 U. ILL. L. REV. 975 (2006) [hereinafter Paredes, On the Decision].

119. Paredes, On the Decision, supra note 117, at 1006-10.

120. Id. at 1010-16.

121. Paredes, supra note 108 , at 18 (citing CASS R. SUNSTEIN, LAWS OF FEAR: BEYOND THE PRECAUTIONARY PRINCIPLE 1020-29 (2005)).

122. See Harvey L. Pitt, Chairman, SEC, Opening Remarks at Investor Summit (May 10, 2002), available at http://www.sec.gov/news/speech/spch560.htm.

123. See Roberta Romano, The Sarbanes-Oxley Act and the Making of Quack Corporate Governance, 114 YALE L.J. 1521, 1523 (2005).

124. Paredes, On the Decision, supra note 117, at 1010-15. 
tendencies. ${ }^{125}$ Hedge fund activities historically have been largely beyond SEC purview. SEC attempts at hedge fund regulation represent a move to seize regulatory turf from other agencies responsible for supervising the system-wide effects of hedge funds. ${ }^{126}$ Similarly, the SEC's conduct has monopolistic attributes: the Agency appears unaware of the costs of its regulation, without comprehension of existing competitive forces and alternatives. ${ }^{127}$

There are also other political-economy explanations for the SEC's conduct. Regulating hedge funds allows the SEC to petition Congress for increased appropriations and staffing to implement such regulation. Furthermore, the SEC's approach pays heed to the general public's oftexpressed fear of these investments as complex, high risk, and a disruptive and negative presence on the U.S. capital market.

The exact mix of these forces is debatable, but it is clear that the SEC never overtly appeared to be acting in response to, or with acknowledgement of, the new capital markets paradigm. ${ }^{128}$

\section{B. Hedge Fund CONSEQuenCES}

Historically, the SEC's prohibitory regulation of public investment in hedge funds would likely suffice to address the above concerns. Retail investors effectively would be barred from hedge fund investment and would no longer be exposed to their labeled, unsuitable risks. However, the new regulatory paradigm compromises the effectiveness of SEC regulation. Ordinary investors still demand hedge fund investments due to their perceived unique and compelling benefits. ${ }^{129}$ The financial market in the new paradigm responds to this demand by engineering permitted investments with characteristics that mimic hedge funds. ${ }^{130}$ Retail investors

125. See generally ANTHONY DOWNS, INSIDE BUREAUCRACY 148-53 (1967) (setting forth the "Law of Ever Expanding Control: The quantity and detail of reporting required by monitoring bureaus tends to rise steadily over time, regardless of the amount or nature of the activity being monitored.").

126. See Jonathan R. Macey, Administrative Agency Obsolescence and Interest Group Formation: A Case Study of the SEC at Sixty, 15 CARDOZO L. REV. 909, 916 (1994) ("[I]nstitutional biases . . provide the best criteria for predicting agency behavior.").

127. This regulatory monopoly position produces an incentive to over-regulate. See Roberta Romano, The Need for Competition in International Securities Regulation, 2 THEORETICAL INQ. L. 387, 392-93 (2001).

128. Nonetheless, it would appear that certain of these forces are dominant. If the SEC were to permit public offering of hedge funds it would also sustain an aggrandizement explanation as well as one species of the political economy explanation due to the increased resources the SEC would require to implement such a regime. We can therefore surmise that the forces delineated above, which sustain restricted investment in hedge funds, are the primary drivers of regulation.

129. See, e.g., sources cited supra note 115 .

130. I term these substitute investments "black market capital" and have written extensively on this phenomenon in Black Market Capital, a companion piece to this essay. See Davidoff, supra note 92 . Investors also purchase these investments through surreptitious means on a true black 
may also seek alternative markets, whether private or foreign, to make hedge fund investments. Finally, retail investors may be prohibited from investing directly in hedge funds but ultimately still become materially exposed to this risk, to the extent it exists, through intermediary investments. The end result is that the SEC's hedge fund regulatory purpose-limiting retail investor exposure to hedge fund risk-is circumvented. And this is exactly what has happened. The remainder of this Part sets forth a number of examples.

\section{Hedge Fund Substitute Products}

Recent hedge fund adviser initial public offerings illustrate the ability of market actors faced with prohibitory regulation to structure financial products side-stepping this bar. Hedge fund advisers are simply that: they are the corporate entities that create and administer the actual hedge and private equity funds. Their revenue and profit is derived principally from the so-called "two-and-twenty"- the typical $2 \%$ administrative fee that the adviser charges with respect to assets under management, and a $20 \%$ profitsharing fee with respect to fund profits over a pre-set hurdle rate. ${ }^{131}$ As such, their performance is derivative of the funds they advise. ${ }^{132}$ The success or failure of a fund adviser is thus almost wholly dependent upon the fortunes of their underlying funds. However, hedge funds themselves are effectively barred from making a public offering because of restrictions imposed by the Investment Company Act ${ }^{133}$ and the Advisers Act. ${ }^{134}$ Yet, unlike the funds themselves, hedge fund advisers do not automatically come under the aegis of these Acts for purposes of these restrictions. Rather, since they are companies whose business happens to be advising hedge funds, they are treated under the federal securities laws as normal operating companies. Consequently, these advisers can publicly raise capital without triggering the application of the Investment Company Act and can otherwise avoid the relevant Advisers Act restrictions on fees. ${ }^{135}$

Hedge fund adviser initial public offerings thus offer a viable alternative for retail investors to derivatively invest in hedge funds. Market actors have embraced this alternative structure. In 2007, there were three

market. They alternatively make foreign purchases where these public investments are legally permitted.

131. See generally DOUGLAS L. HAMmeR ET AL., U.S. REgULATION OF HEDGE FUNDS $\S \S 15.1$, $15.2(2005)$.

132. These advisers also do earn revenue through direct investment in their funds themselves; this is a revenue-stream wholly dependent on fund performance.

133. 15 U.S.C. $\$ \S 80 \mathrm{a}-1$ to -64 (2006).

134. 15 U.S.C. $\$ \S 80 \mathrm{~b}-1$ to -21 (2006).

135. See generally After Blackstone: Should Small Investors Be Exposed to Risks of Hedge Funds?: Hearing Before the Subcomm. on Domestic Policy of the H. Comm. on Oversight and Gov't Reform, 110th Cong. (July 11, 2007) (testımony of Andrew J. Donohue, Dir., Div. of Inv. Mgmt., SEC). 
hedge fund adviser initial public offerings. ${ }^{136}$ These advisers raised an aggregate amount of $\$ 5.186$ billion, comprising $9.2 \%$ of the U.S. initial public offering market during this time period. ${ }^{137}$ The market has succeeded in providing a substitute product for hedge funds, which the SEC does not regulate in a similar manner.

Exchange-traded funds (ETFs) and indexes that have been created to track hedge fund performance are also marketed to retail investors as "hedge fund" substitutes, providing such investors the ability to capture the benefits of hedge funds. ${ }^{138}$ In the United States there are multiple single strategy "hedge fund-type" ETFs. ${ }^{139}$ Many investment advisers now recommend that clients use these single-product ETFs if they want to "build their own" hedge funds. ${ }^{140}$ These ETFs are also often based on index products that attempt to achieve similar returns. It is now estimated that there are twenty-one such indexes for hedge funds. ${ }^{141}$

136. These were Fortress Investment Group, GLG Partners, Inc., and Och-Ziff Capital Management Group. See Och-Ziff Capital Mgmt. Group, Prospectus (Form 424B4), at cover \& 1 (Nov. 13, 2007); Freedom Acquisition Corp., Definitive Proxy Statement (Schedule 14A), at 5 (Oct. 12, 2007); Fortress Investment Group LLC, Prospectus (Form 424B4), at cover \& 1 (Feb. 8, 2007). This figure does not include American Real Estate Partners L.P.'s August 9, 2007 agreement to acquire for approximately $\$ 900$ million Carl C. Icahn's interests in the management company and general partners of the Icahn Funds, which as of June 30, 2007 had approximately $\$ 7$ billion in assets under management. See American Real Estate Partners L.P., Current Report (Form 8-K) (Aug. 9, 2007). The transaction was generally viewed as an alternative way for this fund adviser to go public.

137. Aggregate initial public offering proceeds for 2007 were $\$ 65.34$ billion. See Dealogic Database, U.S. Listed IPOs (search data on file with author).

138. An example is the family of ProShares ETFs. See Rob Wherry, These ETFs Bring HedgeFund Tactics to the Mainstream, SMARTMONEY, Jan. 31, 2007, http:/www.smartmoney.com/ etffocus/?story=20070131; Daisy Maxey, Open \& Shut: Hedging Bets-ETF Industry Joins the Mutual-Fund World in Employing a Trendy Hedge Fund Technique, WALL ST. J., Feb. 4, 2008, at R2.

139. A perusal of the full list of all existent ETFs finds numerous "hedge fund-type" ETFs such as iPath JPY/USD Exchange Rate ETN, Oil Services HOLDRs, and PowerShares DWA Technical Leaders. For a full list of U.S.-listed ETFs, see Mornıngstar, Inc., ETF Performance, Exchange Traded Funds: All, http://news.morningstar.com/etf/lists/ETFReturns.html?topNum= All\&lastRecNum $=1000 \&$ curField $=8 \&$ fsection $=$ etfs $\&$ lpos $=$ FindAMutualFund (last visited Mar. 24, 2008).

140. See, e.g., Timothy Middleton, Build Your Own Hedge Fund, MSN MONEY, Jan. 24, 2006, http://moneycentral.msn.com/content/P140363.asp; Carl T. Delfeld, Buld Your Own Global ETF Hedge Portfolio, SEEKING ALPHA, Mar. 9, 2007, http://seekingalpha.com/article/28993-buildyour-own-global-etf-hedge-portfolio.

141. An example is the Merrill Lynch Equity Volatility Arbitrage Index, which attempts to replicate the returns of an S\&P 500 volatility arbitrage strategy and has a related ETF. See Press Release, Merrill Lynch, Merrill Lynch Creates "Equity Volatility Arbitrage Index" to Replicate Hedge Fund Strategy (Feb. 7, 2007), available at http://www.ml.com/index.asp?id=7695_7696_ 8149_74412_75268_75377. One estimate currently puts the number of hedge fund indexes at twenty-one. See The Hedge Fund Marketing Alliance, Hedge Fund Indexes, http://www.hedgefundmarketing.org/hedgefundindexes.htm (last visited Mar. 24, 2008). See generally François-Serge Lhabitant, Hedge Fund Indices for Retail Investors: UCITS Eligible or Not Eligıble? (Swiss Fin. Inst. Research Paper Series, Paper No. 06-14, 2006), available at http://ssm.com/abstract $=935214$. 
In addition to synthetic hedge funds discussed supra at Part I.C., there is also a new breed of mutual fund: the hedged mutual fund. These funds employ "hedge-fund-like" trading strategies and leverage and hedging to the extent permitted under the Investment Company Act. ${ }^{142}$ As with other hedge fund substitute investments, hedged mutual funds are often marketed to retail investors as hedge fund alternatives. ${ }^{143}$ To accommodate this growth and these new funds, Morningstar has created a new mutual fund category: "Long/Short."144 According to Morningstar, as of December 31, 2007 there were 162 mutual funds under this category. ${ }^{145}$

\section{Black Market Markets}

The private market is also providing alternatives for hedge funds that want the benefits of a public listing but are currently barred from accessing this market or otherwise do not want to do so for other regulatory reasons. The listings of Oaktree and Apollo on GSTrUE are strong examples. ${ }^{146}$

Hedge funds have also responded to U.S. regulatory prohibitions by going abroad to publicly raise capital from retail investors. For example, from 2005 through to 2007 sixteen hedge funds and funds-of-funds sponsored have made initial public offerings on Euronext, the LSE or AIM, raising a total of $\$ 5.578$ billion. ${ }^{147}$ These funds are not just listing in Europe in response to the regulatory bar in the United States on such public capital raising and listing; they are also using the opportunity to tap into demand

142. See generally Vikas Agarwal et al., Hedge Funds for Retail Investors? An Examination of Hedged Mutual Funds (Centre for Fin. Research, Working Paper No. 07-04, 2007), available at http://www.cfr-cologne.de/download/workingpaper/cfr-07-04.pdf.

143. See Forward Launches Hedge Fund in Sheep's Clothing, AllABouTAlPHA.COM, Jan. 14, 2007, http://allaboutalpha.com/blog/2007/01/14/forward-launches-hedge-fund-in-sheeps-clothing/ (commenting on Forward Management's launch of a hedged mutual fund and stating, "here's an example of a mutual fund that is pursuing an all-out hedge fund strategy"); Phil Davis, Hedge Fund Entrepreneurs Could Change Retail Landscape, FIN. TIMES (U.K.), Apr. 17, 2006, at 2 (reporting that hedged mutual funds "known as 'poor man's hedge funds', are becoming increasingly popular in the [U.S.]"); Frederick P. Gabriel, Jr., More Mutual Fund Firms Add Portfolios That Employ Hedging, INVESTMENT NEWS, Jan. 23, 2006, at 3 (reporting that "[i]n an effort to get in on the rising popularity of hedge funds" the Janus Capital Group, Inc. and JP Morgan Chase \& Co. have launched hedged mutual funds); Russ Wiles, Hedged Mutual Funds Offer Defense Strategy, CHI. SUN TIMES, Feb. 14, 2005, at 77 (reporting that "[i]t's the ultimate in blue-collar snob appeal: A growing number of mutual funds now mimic hedge funds").

144. See Dan McNeela, The Long and Short of It, MORNINGSTAR.COM, Mar. 6, 2006, http://news.morningstar.com/articlenet/article.aspx?id=158016\&_qsbpa=y ("Morningstar's new category helps investors find hedge-fund-like strategies.").

145. See Morningstar.com, Fund Returns, http://news.morningstar.com/fundReturns/ FundReturns.html? category=\$FOCA \$LO (last visited Mar. 24, 2008).

146. See supra notes $1-4$ and accompanying text. The Apollo listing is moving to the NYSE, but the Oaktree listing will assumedly move to Portal Alliance with GSTrUE is consolidated into this market.

147. Dealogic Database, Hedge Fund and Hedge Fund Investing IPOs Priced Since 2005 on the Euronext and London Stock Exchange (search data on file with author). 
and offer U.S. investors this public investment opportunity from abroad. ${ }^{148}$ Moreover, the increasing competitiveness of the global capital market and regulators encourages European listings of hedge funds. And the European exchanges are rapidly developing regulatory architecture to accommodate and compete for hedge fund listings. The principal exchanges in Europe competing for these listings are Euronext and the LSE. Euronext has traditionally had a regulatory advantage over the LSE, since the LSE has imposed greater listing and offering strictures than those required by Euronext, which only requires the bare minimum mandated by E.U. regulation. $^{149}$

However, in October 2006, the FSA announced an initiative to consider permitting hedge funds-of-funds to be generally marketed to retail investors. ${ }^{150}$ The FSA is also currently implementing revised LSE listing rules to further accommodate hedge funds and private equity listings. ${ }^{151}$ In anticipation of these rule revisions, the LSE has announced the establishment of a dedicated new market, the Specialist Fund Market, for institutional investors and issuers of single strategy hedge funds and private equity vehicles. ${ }^{152}$ This market, which is deliberately less regulated than the

148. See Davidoff, supra note 92, manuscript at 42 . Given the increased ability of U.S. investors to invest abroad through U.S.-based brokers, this is an opportunity U.S. retail investors can utilize to sidestep prohibitions in the United States. See Aaron Lucchetti, Global Investing Made Easy-Individuals Have More Ways to Buy Overseas Stocks Faster and Cheaper than Ever Before, WALL ST. J., Aug. 12, 2006, at B1.

149. Euronext Amsterdam has attracted a number of listings due to provisions in the Dutch Financial Markets Supervision Act and Euronext Amsterdam's listing rules, which permit fasttrack, light regime listing procedure for international investment companies that have their registered office in States designated by the Finance Minister. See Financial Markets Supervision Act, at $\S 2: 66$ ((Wft) Jan. 1, 2007). To date, this includes Guernsey, Ireland, Jersey, Luxembourg and the United States. See De Brauw Blackstone Westbroek, Memorandum: Dutch Regime on Adequate Supervision Funds $\S 2.3$ (May 2007), available at http://www.nicsa.org/Archives/download/Bermuda07_Groffen.pdf The LSE standards for closedended domestic investment entities are under revision, but are currently set out in chapter 15 of the U.K. Listing Authority's listing rules. See U.K. Listing Auth., Listing Rule 15: Closed-Ended Investment Funds (Jan. 2008), available at http://fsahandbook.info/FSA/html/handbook/LR. The Financial Services Authority (FSA) in the United Kingdom also limits the public marketing of single strategy hedge funds and private equity to retail investors. See generally Fin. Servs. Auth., Wider-Range Retail Investment Products: Consumer Protection in a Rapidly Changing World (U.K. Fin. Servs. Auth., Discussion Paper No. 05/3, 2005), available at http://www.fsa.gov.uk/pubs/discussion/dp05 03.pdf.

150. Press Release, Fin. Servs. Auth. (U.K.), FSA to Consider Extending Range of Retail Investment Products (Mar. 23, 2006), available at http://www.fsa.gov.uk/pages/Library/ Communication/PR/2006/027.shtml.

151. Fin. Servs. Auth., Update on the Investment Entities Listing Review, Apr. 4, 2007, http:/www.fsa.gov.uk/pages/Library/Communication/Statements/2007/investment_entities_ update.shtml.

152. See Press Release, London Stock Exch., London Stock Exchange Launches Specialist Fund Market, (July 12, 2007), available at http://www.londonstockexchange.com/NR/exeres/ CAF85279-3285-47B4-A5A6-E66269A0E8E2.htm. 
LSE's Main Market, was set up to better position the LSE to attract hedge fund listings away from Euronext. ${ }^{153}$

\section{Hedge Fund Intermediation}

The new paradigm results in wider and unanticipated investment by retail investors as they gain exposure to private investments through intermediaries. For example, retail investors are generally barred from investing in hedge funds and private equity because of the high net worth and investment thresholds that these types of investments demand. ${ }^{154}$ Yet, through intermediary investment they may have significant exposure to these investments. ${ }^{155}$ In 2006, it was estimated that pension funds had invested approximately $\$ 50.5$ billion in hedge funds. ${ }^{156}$ And many public companies, such as Goldman, Sachs \& Co. derive significant amounts of revenue from hedge fund type trading strategies. ${ }^{157}$ Thus, despite their SECdetermined unsuitability for retail investment, retail investors still involuntarily or unwittingly have interests in these investments. ${ }^{158}$

\section{CONCLUSION}

The new capital markets paradigm is one of opportunity and challenge. It calls into question the content and structure of the federal securities code, and subjects the SEC as regulator to greater competitive force. But historically, fundamental new securities law is the product of scandal. ${ }^{159}$ Even if the new capital markets paradigm necessitates it, Congress and the SEC are politically unlikely to rework the entirety of securities regulation to reflect these changes in the markets. That is, until a new scandal inevitably arises. ${ }^{160}$

153. See James Quinn \& Yvette Essen, New LSE Market Will Target Hedge Funds, DaILY TELEGRAPH (London), July 13, 2007, City at 4.

154. See discussion supra Part II.A; see also supra notes 106-107 and accompanying text.

155. See SEC Speech, supra note 110 ("In fact, hedge funds are being purchased by intermediaries on behalf of millions of ultimate small investor beneficiaries, retirees, pensioners, and others who are not generally thought of as the traditional hedge fund investor.").

156. See Alan Zibel, Associated Press, Report Warns of Hedge Fund Risks, Feb. 25, 2008, available at $\mathrm{http}: / / \mathrm{biz}$.yahoo.com/ap/080225/hedge_funds_report.html?.v=2.

157. Goldman Sachs Group, Inc., Annual Report (Form 10-K), at 69-73 (Jan. 29, 2008) (reporting $\$ 31.2$ billion in net revenue from Trading and Principal Investments for the year ended November 2007).

158. This investment highlights another possible regulatory irrationality: if retail investors are involuntarily invested in pension funds why can they not invest in hedge funds-of-funds that have a similar investment intermediary structure and through this diversification provide an acceptable risk structure comparable to pension funds?

159. See Stuart Banner, What Causes New Securities Regulation? 300 Years of Evidence, 75 WASH. U. L.Q. 849 (1997) (arguing that new, large-scale federal securities regulation is largely the product of scandal or other public furor). See generally Stephen M. Bainbridge, The Politics of Corporate Governance, 18 HARV. J. L. \& PUB. POL'Y 671, 699-710 (1994-1995).

160. Unfortunately, this can produce unanticipated and damaging regulation as political forces trump rational regulatory processes. See Romano, supra note 122. 
Nonetheless, the new paradigm has the potential to spur the SEC in the near term toward more economic regulation-regulation more responsive to market competition. The forces of financial innovation, particularly increasingly sophisticated academic finance research, also provide the SEC the tools to regulate more intelligently. ${ }^{161}$ The SEC, though, has been slow to account for the new paradigm in its regulation by adopting modern regulatory techniques such as cost-benefit analysis. ${ }^{162}$ The SEC's failure to consider its hedge fund regulation using these tools and with heed to the new paradigm is just one illustration.

But the new paradigm is inevitably coming. The SEC's failure risks not only its competitiveness in the regulated public markets, but it also raises the specter of a regulatory race-to-the-bottom as the new paradigm's competitive forces increasingly force the SEC to act. Yet, without a sound regulatory approach, the SEC has a greater chance of regulating to uneconomical political interests.

A telling illustration comes not just from the SEC's regulatory experience with hedge funds, but also from its recent adoption of relaxed foreign private issuer de-registration rules and rules permitting these issuers to utilize international financial reporting standards when listing and offering securities in the United States. ${ }^{163}$ The SEC did not conduct any substantive cost-benefit analysis or rely on any research or study to regulate with respect to these items. ${ }^{164}$ Instead, the SEC appeared to be deregulating in response to external political forces spurred by competitive pressure. ${ }^{165}$ This regulation might still have been appropriate, but future SEC regulation would be on sounder firmament if the SEC adopted a holistic approach and more rigorous regulatory techniques. The new regulatory paradigm requires not only a rethink of the securities laws but the entirety of the regulatory process.

161. See discussion supra Part I.C.

162. See Sherwin, supra note 94.

163. See Davidoff, supra note 40, at 130-37 (describing this regulatory action).

164. See Termination of a Foreign Private Issuer's Registration of a Class of Securities Under Section 12(g) and Duty to File Reports Under Section 13(a) or 15(d) of the Securities Exchange Act of 1934, Exchange Act Release No. 55,540, 72 Fed. Reg. 16,934 (Apr. 5, 2007) (to be codified at 17 C.F.R. pts. 200, 232, 240, and 249); Acceptance From Foreign Private Issuers of Financial Statements Prepared in Accordance With International Financial Reporting Standards Without Reconciliation to U.S. GAAP, Securities Act Release No. 8879, Exchange Act Release No. 57,026, 73 Fed. Reg. 986 (Jan. 4, 2008).

165. I am referring here to the pressure applied from the financial industry as well as politicians from the State of New York. See, e.g., MCKINSEY \& Co., SUSTAINING NEW YORK'S AND THE U.S.' GLOBAL FINANCIAL SERVICES LEADERSHIP (2007), available at http://www.senate.gov/ schumer/SchumerWebsite/pressroom/special_reports/2007/NY_REPORT \%20_FINAL.pdf. 